\title{
Process analysis transit of municipal waste. Part II - Domestic provisions of law
}

\section{Analiza procesu przewozowego odpadów komunalnych. Część II - Krajowe przepisy prawne}

* Dariusz Starkowski - PhD, Eng. Senior lecturer, Państwowa Wyższa Szkoła Zawodowa w Pile, Instytut Inżynierii Mechanicznej i Transportu, 64-920 Piła, ul. Podchorążych 10. [State Higher School of Vocational Education in Piła. Faculty of Engineering Science and Transport.]
** Paweł Bardziński - MSc, Eng. Director of Logistics Department, Altvater Piła Sp. z o.o. - ENERIS Ochrona Środowiska., 64-920 Piła, ul. Łączna 4 a.

Keywords: road transport, municipal waste, provisions of law, act, regulation

Słowa kluczowe: transport drogowy, odpady komunalne, przepisy prawne, ustawa, rozporządzenie

\section{Abstract}

In 2013, the Polish legal system referring to municipal waste management was restructured in a revolutionary way. The analysis of new provisions of law described in the article requires particular attention, taking into account their place in the entire system of dealing with waste and connections with the remaining elements of this system. At present, Polish regulations lay down the rules of conduct with all types of waste, diversifying a subjective area of responsibility. These assumptions are determined by the provisions of law that are in force in the Republic of Poland. At present, the system of legal provisions is quite complex; however, the provisions of law of the EU constitute its base (the first article). At the level of Polish law, the goals and tasks concerned with dealing with waste were set forth, which leads to tightening of the system. All actions in this respect - from propagating the selective accumulation and collection of municipal waste, keeping the established levels of recycling and recycling of packaging wastes, and limiting the mass of biodegradable waste directed at the storage - is only a beginning of the road to reduction of environmental risks. In this case, permanent monitoring of proper waste dealing in the commune, the province as well as the entire country is essential. Third part of the article will present characterization, division, classification and identification of waste, together with the aspects of logistic process of municipal waste collection and transport.

(C) IOŚ-PIB

The article discusses the process of a road transport operation planning that is connected with municipal waste transport and presents the mixed waste collection on the basis of the transport routes examination. The means of transport are delivered by the service company ALTVATER PIŁA SP. Z O.O. (LLC) - ENERIS in Wałcz commune, located in West Pomeranian voivodeship. The article consists of seven parts, all of which depict the elements of planning and transport processes of municipal waste in road transport from legal, technical and economic perspective. Information provided in the article concerns the legal background

\section{Streszczenie}

W roku 2013 polski system prawny odnoszący się do postępowania z odpadami komunalnymi został przebudowany w sposób rewolucyjny. Analiza nowych przepisów prawnych przedstawiona w artykule wymaga szczególnej uwagi, w tym uwzględnienia ich miejsca w całym systemie postępowania z odpadami i powiązań z pozostałymi elementami tego systemu. Obecnie polskie regulacje prawne ustalają zasady postępowania z każdym rodzajem odpadów, różnicując podmiotowy zakres odpowiedzialności. Założenia te określane są przepisami prawa obowiązującego na terenie RP. W chwili obecnej jest to bardzo rozbudowany zespół przepisów, przy czym podstawę dla przepisów wewnętrznych stanowią przepisy prawa unijnego (część pierwsza). Na szczeblu prawa polskiego ustalone zostały cele i zadania dotyczące właściwego postępowania z odpadami, które prowadzić mają do uszczelnienia systemu. Wszelkie działania w tym zakresie, od propagowania selektywnego gromadzenia i zbierania odpadów komunalnych, po nałożone prawem osiąganie ustalonych poziomów odzysku i recyklingu odpadów opakowaniowych oraz ograniczenia masy odpadów ulegających biodegradacji kierowanych do składowania są dopiero początkiem drogi do maksymalnego zmniejszenia zagrożeń dla środowiska. Niezbędnym jest w tym wypadku stałe monitorowanie właściwego postępowania z odpadami komunalnymi zarówno na szczeblu gminy, województwa jak i kraju. W trzeciej części artykułu zostanie przedstawiona charakterystyka, podział, klasyfikacja i identyfikacja odpadów oraz aspekty procesu logistycznego zbiórki i transportu odpadów komunalnych.

related to waste collection and management, road transport of goods (waste) and the requirements that have to be met by the service company that carries out the transport and conducts business activity. Moreover, technical and legal aspects of vehicles used for municipal waste transport were described. Optimal routes for commune management were prepared in the light of technological transport process, together with all the actions that accompany the said process. The assumptions of municipal waste management system were detailed, including the obligations and duties of communes that stem from the necessity 
of the mentioned process organization, the rules of dealing with waste that the transporting entity incorporates and the possibilities of waste management. The third part of the article is to present the analysis of basic national legal regulations concerning the municipal waste management in view of logistics that has a decisive impact on an integrated logistic system operations, which support the waste management in utility company.

\section{INTRODUCTION}

Methods of municipal waste management have changed radically in recent years, both in terms of waste collection and treatment. The underlying cause of the changes is law amendment that Poland had to introduce under supervision of the European Union. New legal provisions that were set forth in Poland and objectives that are determined, concern proper waste dealing and tighten the system. All actions that are undertaken in this area, from selective waste storing and collection, to legally enforced achievement of certain levels of recovery and packaging waste recycling and limiting the weight of biodegradable waste directed towards the collection, are just a prelude to minimizing threats for the environment. It seems vital to provide constant control of proper waste dealing at the level of a commune, a voivodeship and a country.

\section{NATIONAL PROVISIONS OF LAW}

Year 2013 brought revolutionary changes in legal system that pertain to municipal waste management. New regulations have to be analysed with caution and their place in the whole system of several elements of waste treatment need to be taken into consideration. Article 86 of the Polish Constitution states that everyone shall care for the quality of environment and shall be held responsible for causing its degradation. Waste production is one of the ways of possible degradation. Thus, an undertaking should aim at limiting the amount of waste or its elimination, and in case of generated waste, the management needs to be carried out in compliance with legal regulations. The responsibility of the undertaking usually consists of transferring waste to specialized entity and incurring expenses of waste disposal.

Main state regulations are:

a) Act on maintenance of the commune in a clean and orderly condition of 13 September 1996 (Polish Journal of Laws 2013 item. 1399) [Act on maintenance of the commune in a clean and orderly condition ......2013].

The act specifies tasks of the commune and owners of real estates in order to maintain order.

It also gives requirements that an entity needs to meet to be granted a permit to provide services and it describes the ways of waste management. An authorization is issued by a commune head, commune mayor or mayor for a period no longer than 10 years. The instrument determines what activities from the scope of waste management belong to the commune. Such an authorization may be withdrawn in cases where a legally binding decision concerning the entrepreneur is entered or an undertaking ceased to perform waste collection, waste is transmitted for a second time as municipal waste or an undertaking did not achieve the specified level of recycling during a calendar year. The act lays down the way that waste management should be carried out from the moment of collection to the moment of waste disposal. The act provides that the commune should quarterly carry out a report on the amount of collected waste, biodegradable waste and the number of real estate owners from whom waste is collected. The report should include a list of real estate owners who collect waste in a way that is inconsistent with regulations and it needs to be delivered to the head of commune, commune mayor or city mayor. Next, a yearly report is given to the marshal of the voivodeship. What seems to be important is the issuing of tenders for waste collection that is the responsibility of the commune. The commune or the undertaking hired by the commune to collect waste has to provide bulky waste points for the residents of properties. The property owners that dispose of their waste need to ensure favourable conditions for the workers that remove waste. At the same time, property owners are obliged to segregate waste in accordance with specific regulations. All containers that are given should be used for the intended purpose and should be in good technical and sanitary conditions. The commune needs to guarantee accessibility to waste containers that are localized in the premises of the commune. The communes that have over 1000 inhabitants are obligated to determine a point of selective waste collection [Poskrobko et al. 2012 ]. The town council specifies the amount of charges for waste collection, which is dependent on the number of inhabitants in a house or a flat. The council may also reduce the waste collection charges, if a selective waste collection is carried out by the inhabitants.

b) Regulation of the Minister of Environment of 9 December 2014 on waste catalogues (Polish Journal of Laws of 2014 item. 1923).

The regulation introduces a division of waste into groups and sub-groups, and points out another division with regard to hazardous waste. Waste is partitioned into 20 groups depending on the source of waste.

The regulation specifies the amount of charges for unit gas rates, substances, groundwater abstraction and waste collection. Fees include sewage, gas and dust that go into the atmospheric system.

c) Regulation of the Minister of Environment of 12 December 2014 on the specimen documents used for the registration of waste (Polish Journal of Laws of 2014 item. 1973).

The Act contains the specimen of documents, for example, a card of waste evidence, hazardous waste, used electrical equipment evidence and end-of-life vehicle evidence.

The regulation is very transparent as it contains only the specimen of the mentioned documents.

d) Act of 11 September 2015 on used electrical and electronic equipment (Polish Journal of Laws of 2015 item. 1688).

The Act is intended to minimize the influence of used electronic equipment on the environment and facilitate the 
process of electronic waste storage and reuse. The main role of the Act, however, is to reduce the negative impact of electronic waste on human health and life.

The document defines the rules of the waste bringing out to the market, its collection, processing or disposal. The equipment recovery and the amount of product fee is described as well. Moreover, main duties of public administration are scrutinized along with fines that may be imposed on an undertaking. Because of the fact that every equipment introduced into the market has to be labelled in a proper way in terms of its usage in a household, the Act describes the labelling rules of equipment predestined to selective waste collection.

The producer is obliged to give information on the reuse of the equipment and on the parts that it contains. By the time the equipment is introduced to the market, the producer has to demonstrate attaining certain level of recycling of waste and is expected to possess financial security for a calendar year. Next, a person who disposes of equipment is not allowed to mix it with other waste. The equipment needs to be complete and verified as a household appliance. Recovery and recycling should take place in a designated plant. Organizations that deal with recovery need to carry out public educational campaigns in a calendar year and devote $5 \%$ of net income to this purpose.

Every year there is an audit carried out to verify if the proceedings in a recovery plant are correct, which enables the plant to function if the requirements are met. Product fees are introduced when a minimal yearly limit for equipment recovery is not reached - dependent on kilograms of waste. All recovery proceedings are connected with making registers and reports, which are checked every year by voivodeship environmental protection inspector. The supervision ends with a report that is handed over to the main environmental protection inspector. The Act defines the amount of fine imposed on plant owners if the rules are not abided by.

e) Act of 14 December 2013 on waste (Polish Journal of Laws of 2015 item. 87). Notice of the Marshal of the Sejm of the Republic of Poland on 7 November 2016 on announcing a consolidated text of an Act on waste. Journal of Laws of 2016 item. 1987 [Act of 14 December 2013 on waste .....2013]. The Act defines all means that are to be used in order to protect the environment, human health and life. Those means should prevent and reduce a negative impact on the environment and human health caused in the process of waste production and management. Pursuant to the Act, there is a certain hierarchy of proceedings in respect of waste management, which the entities that take actions causing waste production should follow:

1. prevent the production of waste and reduce the amount of waste and its negative environmental impact during the production of products, during and after use of products;

2. provide recovery in accordance with the environmental principles, if it was not possible to prevent waste;

3. provide, in accordance with the environmental principles, disposal of waste, the creation of which could not be prevented, or which could not be recovered.
Waste owners are obliged to deal with waste in a manner that is consistent with waste management regulations, requirements of the environmental protection, and waste treatment plans. Moreover, waste should be collected in a selective way and it is forbidden to recover or dispose of waste in places other than special plants and installations designed for that [Stanislawska et al. 2015]. The Act contains proposed changes and their positive influence on the environment through:

1. creating common registry of entities that introduce packaging, packed products, batteries and accumulators, electronic and electrical, vehicles, tires, equipment and oils. Also, entities that manage waste should be listed, which would help in a fast identification and better control over waste management system;

2. developing programs preventing waste creation that would determine the aims of such prevention and quantitative reference levels for adopted means of waste prevention in order to oversee the progress in this field;

3. taking actions to determine the end-of-waste status, acknowledging waste as a by-product and preparing for its reuse that leads to the support of reuse of materials and products, and in turn, by reducing the usage of raw materials to protect natural resources;

4. limiting the amount of stored waste to the benefit of recycling and other forms of recovery, in particular, through the implementation of a wider hierarchy of waste management. Moreover, shaping the management of waste and legislative measures in a way that would encourage to create and support the reuse and mending, defining the criteria of public procurement, economic incentives and other proper means;

5. introducing an obligation of testing the physical and chemical properties of all waste that is a residue of incineration (not only hazardous waste), which will lead to the right choice of waste treatment depending on its qualities.

f) Regulation of the Minister of Environment of 11 January 2013 on detailed requirements concerning municipal waste collection from properties owners (Polish Journal of Laws of 2013 item.122).

The regulation defines requirements for the entities that specialize in municipal waste collection from property owners. The problem of equipment, labelling and assuring good technical and sanitary condition of waste collecting vehicles is approached in detail.

It also covers a range to which proper equipment and location of a storage-transport unit should be provided.

g) Regulation of the Minister of Environment of 12 December 2014 on types and quantity of waste which is exempted from stock records (Polish Journal of Laws of 2014 item. 1974).

h) Regulation of the Minister of Economy of 16 January 2015 on types of waste that can be stocked at a waste landfill in nonselective way (Polish Journal of Laws of 2015 item.110). 
The regulation specifies particular groups and subgroups which may be stocked together without segregation and lists the types of waste for which the collection is exempted from record.

i) Act of 13 June 2013 on management of packaging and packaging waste (Polish Journal of Laws of 2015 item.1688).

The Act lays down requirements that the packaging needs to meet in order to place it on the market. Rules of packaging recovery and dealing with packaging waste are specified in the Act as well.

j) Regulation of the Minister of Environment of 3 August 2014 on the specimen documents used for the registration of waste (Polish Journal of Laws of 2014 item.1298).

It describes the specimen of packaging labelling which lists the types of materials it contains. It pertains mainly to the packaging made of plastic, paper, paperboard, steel, wood, jute and glass. Knowledge of the specimen is vital in order to identify and determine if there is a possibility of recycling.

k) Act of 6 August 2001 on road transport (Polish Journal of Laws of 2001 no 125 item.1371 as amended).

The regulation introduces Regulation (EC) No 1071/2009 of the European Parliament and the Council of 21 October 2008 on establishing common rules concerning the conditions to be complied with to pursue the occupation of road transport. Moreover, it brings in the rules of Regulation (EC) No $1072 / 2009$ of the European Parliament and the Council of 21 October 2009 on common access to international market of road transport [Starkowski et al. 2012]. The most common legal problem in a municipal company is the workers' inability to distinguish between the type of carriage (commercial/ municipal/for own account) done on the same day, with the same vehicle (garbage truck), and same driver, which leads to serious legal irregularities in the scope of license rules and record of periods when vehicles are used, and when a break takes place. Other mistakes that occur are: lack of entry of appropriate vehicles into a license/certificate (the fine for each vehicle is 8000 PLN) [Rześny-Cieplińska 2011]. Provisions of law on road transport set forth that a 'municipality company' may conduct a licensed transport as well as transport for own account. However, own account transport may be carried out in two ways:

a) on the general principles - which, due to the specificity of some municipality companies, is hard to implement;

b) on the basis of exclusion - exception (which may be incorporated by some companies where a transport is not conducted under license);

Legal provisions on road transport are implemented when there is a transport of:

a) municipal waste, or

b) liquid waste on the analogical basis, as in the case of transport for own account.
That is the only case when a municipal company may conduct transport of waste under a certificate on transport of own account based on exclusion.

The analyses of the agreements (their type) between municipal companies and contractors - it often turns out that they cannot conduct transport of own account [Starkowski et al. 2011]. Within the framework of municipal waste transport services or liquid waste transport, municipal companies do not have to conduct transport solely under a license. As it was said before, according to the definition of 'municipal waste', [Waste Act of 14 December 2012 [OJ 2016 pos. 1987], in force since 23 January 2013 defines municipal waste as waste generated by households, with the exception of end of life vehicles, as well as waste containing hazardous waste coming from other waste, which is similar to the waste from households because of its nature or composition. When it comes to municipal companies, there applies a Regulation (EC) No 561/2006 (concerning driving time and break periods of drivers in municipality companies). Every member state may introduce some exclusions concerning Regulation (EC) No 561 of the European Parliament and the Council of 15 March 2006, which according to article 13(1) h) - 'to transport conducted with vehicles in connection with discharge of sewage (...) collection of waste from households and its removal'. Poland introduced exemption from obeying Regulation (EC) 561/2006 on the basis of article 29 (1)(2) of an Act of 16 April 2004 on driver's working time. Analysis of standards depicted in article 13(1)(h) of Regulation (EC) No 561/2006 shows that exemption from rules concerning driver's working time (in consequence a duty of using a tachograph - on the basis of a state act) relates to carriage conducted in scope of households' waste collection and removal.

If a vehicle collects 'household' waste (including housing communities waste), then: [Act from 16 April 2004 about the time of the work of drivers ......2004]

a) drivers do not have to use tachographs,

b) drivers do not have to fill in record sheets,

c) drivers do not have to use drivers' cards,

d) drivers do not have to comply with rules of driver's working time,

e) drivers do not have to comply with rules of rest,

f) drivers do not have to comply with rules of break.

In this case, drivers need to comply with the rules stipulated in an Act on driver's working time, because on the basis of Article 29 of this Act, the working time of drivers: 'Vehicles categories which are mentioned in Article 13(1) specified in the working time of drivers from 2014, it shall be exempted from the application of Article 5-9 of the said regulation'. Hence, not all temporal rules (driving time, rest and breaks) are used in transport. 


\section{CONCLUSIONS}

Waste management has changed substantially in last few years in terms of the way that waste is collected, transported and handled. Amendment of Polish law that was necessary in order to comply with the laws of the European Union underpins the change (first article). Municipal waste transport is not an easy task, that's why what a carrier should bear in mind when planning a transport is: legal provisions, range and type of waste, chemical and physical structure of waste and duration of transport that entails a choice of a proper vehicle. Ignoring even one of the mentioned issues may lead to environmental pollution, contamination of groundwater and people poisoning, which puts consumer in danger and exposes a carrier to financial losses and criminal liability. The analyses of legal status of most of the Polish municipality companies show that in majority of cases, the subject matter of the contract is: providing

\section{REFERENCES}

POSKROBKO B. POSKROBKO T. 2012. Zarządzanie środowiskiem w Polsce. Polskie Wydawnictwo ekonomiczne. Warszawa

RZEŚNY- CIEPLIŃSKA J. 2011. Organizatorzy transportu: Rynkioperacje-strategie. Wydawnictwo Uniwersytetu Gdańskiego, Gdańsk

STANISŁAWSKA I ., BARDZIŃSKI P., KALKA J. 2015. Praca dyplomowa na studiach podyplomowych. „Od umowy do utylizacji, czyli kompleksowa gospodarka odpadami komunalnymi po nowelizacji ustawy o utrzymaniu czystości i porządku w gminach". Wyższa Szkoła Logistyki

STARKOWSKI D., BIEŃCZAK K., ZWIERZYCKI W. 2012 Samochodowy transport krajowy i międzynarodowy. Przepisy w transporcie drogowym. Tom 4, Systherm

STARKOWSKI D., BIEŃCZAK K., ZWIERZYCKI W. 2011. Samochodowy transport krajowy i międzynarodowy. Przepisy prawne. Tom 2, Systherm services with regard to waste management - reception, transport from the places that produce waste, collection, storage, recovery and waste disposal, or passing waste to entities that are authorized to conduct recovery and disposal. Some undertakings do not exhibit solely auxiliary character of collection/transport of waste, particularly due to a clause in the contract that a Contractor carries out waste recovery/disposal or passes on to authorized entities to perform these tasks. Moreover, as the provision of a contract indicates, transport has to be conducted non-commercially, whereas most of the contracts are designed in such a way that a Contractor gets paid for the services (very often contracts contain a provision which says that prices include costs of transport). Such a provision excludes the possibility of transport for own account as the contract suggests commercial character of the service. Knowledge of national regulations of law is a basic condition of safe and proper municipal waste transport planning in Poland.

USTAWA z dnia 13.09.1996 r. o utrzymaniu czystości i porządku w gminach (Dz. U. z 2013 r. poz. 1399). [Act on maintenance of the commune in a clean and orderly condition of 13 September 1996] (Polish Journal of Laws 2013 item. 1399).

USTAWA z dnia 16 kwietnia 2004 r. o czasie pracy kierowców (Dz.U. z 2004 r. Nr 92, poz. 879 ). [Act from 16 April 2004 about the time of the work of drivers of the Journal of Laws from 2004 No. 92, pos. 879].

USTAWA z dnia 14 grudnia 2013 roku o odpadach (Dz.U. 2015 poz. 87). Obwieszczenie Marszałka Sejmu Rzeczypospolitej Polskiej z dnia 7 listopada 2016 r. w sprawie ogłoszenia jednolitego tekstu ustawy o odpadach. Dziennik Ustaw rok 2016 poz.1987. [Act of 14 December 2013 on waste (Polish Journal of Laws of 2015 item. 87). Notice of the Marshal of the Sejm of the Republic of Poland on 7 November 2016 on announcing a consolidated text of an Act on waste. Journal of Laws of 2016 item. 1987]. 